\title{
Bank-based versus Market-based Financial Systems: A Growth-theoretic Analysis*
}

\author{
Shankha Chakraborty ${ }^{\dagger}$ Tridip RaY R $^{\dagger}$
}

\begin{abstract}
We study bank-based and market-based financial systems in an endogenous growth model. Lending to firms is fraught with moral hazard as owner-managers may reduce investment profitability to enjoy private benefits. Bank monitoring partially resolves the agency problem, while market-finance is more 'hands-off'. A bank-based or market-based system emerges from firm-financing choices. It is not possible to say unequivocally which of the two systems is better for growth. The growth rate depends, crucially, on the efficiency of financial and legal institutions. But a bank-based system outperforms a market-based one along other dimensions. Investment and per capita income are higher, and income inequality lower, under a bank-based system. Bank-based systems are more conducive for broad-based industrialization. A temporary income redistribution, under both financial systems, results in permanent improvement in per capita income as well as income distribution.
\end{abstract}

Keywords: Financial System, Income Distribution, Banks, Market Finance JEL Classification: E22, G20, O15, O16,

\footnotetext{
*We thank Leonard Cheng, Jangok Cho, David Cook, Sudipto Dasgupta, George Evans, Vidhan Goyal, Jo Anna Gray, Philippe Marcoul, Nobuhiro Kiyotaki, Francis Lui, Cheol Park, Xiaodong Zhu and seminar participants at the Delhi School of Economics, Hong Kong University of Science and Technology, Iowa State, Indian Statistical Institute (Delhi), University of Hong Kong, the 2001 NEUDC Conference (Boston) and the 2002 Midwest Macro Conference (Vanderbilt), for helpful comments and discussions. The usual caveat applies.

${ }^{\dagger}$ Department of Economics, University of Oregon, Eugene, OR 97403-1285. shankhac@oregon. uoregon.edu

${ }^{\ddagger}$ Department of Economics, Hong Kong University of Science \& Technology, Clear Water Bay, Kowloon, Hong Kong. tridip@ust.hk
} 


\section{Introduction}

This paper is a theoretical analysis of bank-based and market-based financial systems in economic growth and development.

We are motivated to study this particular issue because of a long-standing debate on the relative importance of the two systems. The success of market-based systems in the US and UK have led some observers to tout their virtues, while others have advocated bankbased systems because of their vital role in German and Japanese industrialization. ${ }^{1}$ Eastern Europe and Latin America's financial liberalization of the 1990s has revived this debate market-based systems are being seen as more dependable for growth and development (Allen and Gale, 2000).

We examine this debate in an endogenous growth model. Availability of bank and/or market finance enables firms to make larger investment than is possible otherwise. It also allows entrepreneurs in the traditional sector to overcome large-scale investment requirements of entering the modern sector. A bank-based or market-based system emerges endogenously.

Two countries may have different financial regimes, yet enjoy similar rates of economic progress; what matters for growth is the efficiency with which a country's financial and legal institutions resolve agency problems, rather than the type of system it relies upon. From a development perspective, however, a bank-based system outperforms a market-based one - financial intermediation creates an environment more conducive for transforming a traditional economy into a modern one.

With the availability of systematic evidence during the past decade, the relevance of finance for development is now widely accepted. This evidence shows a positive and robust relationship between financial development and growth, the level of financial development being a good predictor of future growth and technological change. ${ }^{2}$ Concurrently, an extensive theoretical literature on financial institutions has developed. Research in corporate finance has examined firm financing choices, while growth theorists have studied the role of finance in capital and knowledge accumulation.

In corporate finance, the organization of financial activities is seen to affect growth through corporate governance and a firm's ability to raise external funds. Financial intermediaries reduce costs of acquiring and processing information about firms and their managers

\footnotetext{
${ }^{1}$ See Allen and Gale (2000), Holmstrom (1996) and Levine (2000) for details.

${ }^{2}$ Gerschenkron (1962), Goldsmith (1969) and Gurley and Shaw (1955) were among the first to discuss the importance of finance for growth; a comprehensive summary of more recent findings is contained in Levine (1997).
} 
and thereby reduce agency costs (Boyd and Prescott, 1986; Diamond, 1984). By assuming the role of a 'delegated monitor', they also avoid wasteful duplication of information.

In Holmstrom and Tirole (1997), bank- and market-finance are distinguished according to their information content. Bank monitoring resolves moral-hazard problems at the level of the firm. Firms with lower marketable collateral and higher incentive problems borrow from banks, while wealthier firms rely on unintermediated market-finance. Hence, as Boot and Thakor (1997) point out, bank lending is likely to be important when investors face $e x$ post moral hazard problems, with firms of higher observable qualities borrowing from the capital market.

Some authors have also highlighted how market finance creates appropriate incentives for a firm. In Scharfstein (1988), equity markets encourage corporate governance through hostile takeovers of under-performing firms. Rajan and Zingales (1998b, 1999) argue that market-finance transmits price signals which guides firms into making worthwhile investments. Relationship-based bank finance, in contrast, could lead firms facing weak cash flows to undertake misguided investments.

Contributions on finance and growth are many. ${ }^{3}$ Among them, Greenwood and Jovanovic (1990), Bencivenga and Smith (1991) and de la Fuente and Marin (1996) show that financial intermediaries promote growth by pooling risks, providing liquidity and monitoring risky innovations. Greenwood and Smith (1997), on the other hand, analyze how financial markets assist growth through increased specialization. But growth theory has been largely silent on the 'bank versus market' debate, stressing the importance of either banks or financial markets. $^{4}$

In recent years, policymakers have been advocating a shift toward financial markets, particularly in Latin America and Eastern Europe where financial systems similar to those in the US have been proposed (Allen and Gale, 2000). It is, however, unclear why marketbased systems necessarily dominate bank-based ones. As Levine (1997, pp. 702-703) points out, "we do not have adequate theories of why different financial structures emerge or why financial structures change...we need models that elucidate the conditions, if any, under which different financial structures are better at mitigating information and transaction costs." It is precisely here that the chief contribution of our paper lies.

\footnotetext{
${ }^{3}$ This literature also branches into analyzing the role of credit markets in business cycles. See Williamson (1986, 1987), Bernanke and Gertler (1989) for early contributions and Bernanke et al. (2000) for a recent overview.

${ }^{4}$ Boyd and Smith (1998) do allow for a simultaneous choice of bank- and market-finance. But they focus on how the mix changes over time.
} 
Finance is relevant for growth and development for two main reasons. Better developed financial systems resolve agency problems better. This enables firms to borrow at cheaper rates and invest more. ${ }^{5}$ But finance also plays a role in structural transformation. A key characteristic of developing countries is their dualistic structure - the coexistence of pockets of modern manufacturing activity with widespread peasant farming and cottage-industry production. Transition from the traditional sector to the modern is not always simple: manufacturing activities usually require lumpy investments that may not be forthcoming in the absence of well-developed financial systems. ${ }^{6}$

These complementary roles are built into an $A k$-type endogenous growth model with overlapping generations of families. A set of agents (entrepreneurs) convert final goods into capital using a modern-sector technology that requires a minimum investment size to cover setup costs. Entrepreneurs who are able to obtain the requisite amount of finance enter the modern-sector and produce capital. Those who do not, engage in traditional activities like peasant farming and household production.

As in the corporate finance literature, we distinguish between bank-finance and marketfinance based upon their involvement with investment projects. Banks are typically more 'hands-on', engaged in project selection, monitoring firms and identifying promising entrepreneurs. On the other hand, investment through the purchase of tradeable securities, or market-finance, is more of an arm's length transaction, with very little subsequent involvement in a firm's investment decisions. To justify a role for both types of finance, we introduce moral hazard at the level of the entrepreneur. Specifically, we adapt Holmstrom and Tirole's (1997) agency problem to a dynamic setting. Entrepreneurs who obtain external finance may deliberately reduce the success probability of their investment in order to enjoy private benefits. Outside investors, or the market, are too disparate to effectively control a borrower's activities. Financial intermediaries, on the other hand, monitor entrepreneurs and (partially) resolve the agency problem. But since monitoring is costly, bank finance is more expensive than market finance.

A key determinant of financing choices is an entrepreneur's initial wealth. Entrepreneurs with lower wealth have more incentive to be self-serving than wealthier ones. One way to

\footnotetext{
${ }^{5}$ Rajan and Zingales (1998a) use industry-level data to show that more developed financial regimes promote growth by reducing the cost of borrowing.

${ }^{6}$ The effect of capital market imperfections on inequality have been studied by Galor and Zeira (1993) for human capital investment, and Banerjee and Newman (1993) for occupational choice. Hicks (1969) as well as North (1981) deliberate on the role of finance in overcoming large-scale investment requirements during the Industrial Revolution.
} 
mitigate this incentive gap is to borrow, at a higher rate, from a bank and agree to being monitored. In contrast, wealthier entrepreneurs rely more on market finance as they face less of an information gap. In certain cases, for instance when the fixed cost of modern sector activities are large, even bank monitoring is not a sufficient substitute for entrepreneurial wealth - the poorest entrepreneurs are unable to get any type of external finance. ${ }^{7}$

A bank-based system, where intermediation plays a key role, or a market-based system, where all lending is unintermediated, evolve endogenously in our model. A bank-based system emerges when monitoring costs are modest and when agency problems are significantly extenuated through monitoring. When agency problems are not particularly severe, or when monitoring is expensive, a market-based system emerges.

The growth rate under either regime is a function of the efficiency of the system - betterfunctioning legal systems make contracts easier to enforce and reduce monitoring costs as also the cost of direct lending. Investment is higher, as is the growth rate of per capita income. In this, our results square well with the 'legal-based' view espoused more recently by LaPorta et al. $(1997,1998)$ and for which Levine (2000) finds strong cross-country evidence.

When legal and financial institutions are especially underdeveloped, agency problems are severe; a financial sector, if it exists, is primitive and allows for limited amount of borrowing and lending. Much of economic production will be in activities like peasant agriculture and cottage-industry production, activities that do not rely upon financial markets but also yield low-returns.

Although neither a bank-based nor a market-based system is specifically better for growth, our model suggests some advantages to having a bank-based system. In particular, since bank monitoring substitutes for entrepreneurial wealth, it enables all modern-sector firms to make larger investments than is possible under purely unintermediated finance. It also lowers the minimum entrepreneurial wealth required to obtain external finance so that the traditional sector is smaller under a bank-based system. Hence, even when a bank-based and a market-based economy grow at similar rates and have similar wealth distributions, per capita GDP in the former is permanently higher.

Our model predicts rising inequality along the economy's long-run growth path: income levels in the traditional sector stagnate, while the modern-sector enjoys sustained improvements in living standards. Therefore, to address equity concerns, we consider the role of policy interventions. Financial and legal reforms which reduce agency problems make it eas-

\footnotetext{
${ }^{7}$ The role of initial wealth for financing choices is particularly relevant in light of evidence that even in developed countries approximately $70 \%$ of new investment in physical capital is financed out of retained earnings (Mayer, 1988). See Allen and Gale (2001) for more recent evidence.
} 
ier for modern-sector entrepreneurs to borrow. This raises the investment rate, and hence GDP growth, under both types of financial system. However, in a bank-based system, these reforms also have a level effect on per capita income. By lowering the minimum wealth needed to raise external finance, they assist some traditional sector entrepreneurs to enter the modern sector - per capita GDP rises as more entrepreneurs switch from home production to the manufacture of high-productivity capital goods. In contrast, reforms in a market-based system may leave the traditional sector relatively worse-off unless they specifically reduce the costs of bank intermediation. In both regimes, a temporary income redistribution has permanent effects on the level of per capita income and on income distribution.

The paper is organized as follows. We lay out the structure of the economy in Section 2. Sections 3 and 4 discuss financing options that an entrepreneur faces and her optimal investment decision. In Section 5 we characterize the balanced growth path for the economy. We discuss implications of the model and effects of policies in Section 6. Section 7 concludes.

\section{The Environment}

Time is discrete, continues forever and is indexed by $t=0,1,2, \ldots, \infty$. A continuum of two-period lived agents are born every period. These agents are of two types: a fraction $\mu$ of them are working households, the remaining ones entrepreneurs.

Without loss of generality, let us normalize $\mu$ to $1 / 2$ and the measure of households and entrepreneurs each to unity. There is no population growth; each agent gives birth to one offspring at the end of her youth.

Economic activity encompasses a final goods sector that produces the unique consumption good, a capital goods sector that supplies inputs to final goods producing firms, and a financial sector that channels funds from lenders to borrowers.

\subsection{Economic Agents}

A household is born with one unit of labor time in youth which it supplies inelastically to the labor market. A generation- $t$ household's lifetime utility depends only upon 'old-age' consumption. This means the entire wage income, $w_{t}$, is saved. Households are the natural lenders in this economy. They invest their savings on the financial market earning a (gross) return $R^{*}$.

An entrepreneur is also born with one unit of labor time in youth that she uses to operate either of two types of technologies. Using a modern technology she can convert units of the 
final good into a marketable capital good. Or else, she can engage in non-marketed cottageindustry or household production of the final good.

Entrepreneurs are altruistic, deriving utility from their old-age consumption and the amount of bequests they leave to their offspring. A typical generation- $t$ entrepreneur's preferences are given by the 'warm-glow' (Galor and Zeira, 1993) utility function:

$$
U_{t}^{E}=\beta \ln c_{t+1}^{E}+(1-\beta) \ln b_{t+1}, \beta \in(0,1)
$$

where $b_{t+1}$ denotes bequests made. Thus, an entrepreneur also has a wealth-endowment in youth that she receives as bequest.

Preferences for households and entrepreneurs are posited to be different for a simple reason. We shall shortly identify each entrepreneur with a capital good producing 'firm'. The bequest motive in (2.1) essentially captures the continuity of each such firm in a dynamic production economy. Altruism among households can be readily incorporated without qualitatively altering any of our basic results.

Let us index an entrepreneur by $j \in[0,1]$ and denote her initial wealth at date- $t$ by $b_{t}^{j}$. Wealth distribution among generation- $t$ entrepreneurs is described by the cumulative distribution function $G_{t}(b)$, indicating the proportion of them with wealth less than $b$. Given logarithmic preferences, entrepreneur- $j$ bequeaths a constant proportion of her realized oldage income $z_{t+1}^{j}$ :

$$
b_{t+1}^{j}=(1-\beta) z_{t+1}^{j} .
$$

Given an initial wealth distribution $G_{0}$ and entrepreneurial income $\left\{z_{t+1}^{j}\right\}_{t=0}^{\infty}$, equation (2.2) tracks the wealth distribution through time. ${ }^{8}$

\subsection{Production Technologies}

\section{Final Goods Sector}

Competitive firms produce the final consumption good combining raw labor with capital goods. The underlying private technology is constant returns in capital and labor inputs:

$$
Y_{t}=A_{t} N_{t}^{1-\alpha}\left[\int_{j \in E_{t}} K_{t}^{j} d G_{t}\right]^{\alpha}, 0<\alpha<1 .
$$

Here $E_{t}$ denotes the set of entrepreneurs who supply capital goods at date- $t$ and $A_{t}$ denotes the efficiency of technology.

\footnotetext{
${ }^{8}$ It is sufficient to assume that the initial old generation of entrepreneurs are endowed with capital $\left\{k_{0}^{j}\right\}$. These entrepreneurs rent out the capital, earning a gross return $\rho_{0}$, and leave bequests $b_{0}^{j}=(1-\beta) \rho_{0} k_{0}^{j}$, which then defines the initial distribution of bequests, $G_{0}(b)$.
} 
Following Arrow (1962) and Romer (1986), we allow for technological spillover from private investments to the aggregate technology. In particular, efficiency of the final goods sector improves with increased capital intensity of production:

$$
A_{t}=A k_{t}^{1-\alpha}
$$

where $k_{t} \equiv K_{t} / N_{t} \equiv\left[\int_{j \in E_{t}} K_{t}^{j} d G_{t}\right] / N_{t}$ denotes aggregate capital per worker. This effectively transforms the social per worker production function into

$$
y_{t}=A k_{t}
$$

with constant marginal product of capital.

One way to justify such non-diminishing returns is to interpret capital broadly, as comprising not only the stock of physical capital such as buildings, machinery and public infrastructure, but also the outcome of investment in innovative activity. By simply observing the activities of others, final goods producing firms learn how to improve their production processes. In particular, the 'knowledge function' (2.3) is meant to capture Arrow's idea that efficiency gains arise from investment in capital and are non-rival in nature.

Final goods producers hire labor and capital and sell their output in perfectly competitive markets. The equilibrium rental and wage rates are then given by

$$
\begin{aligned}
& \rho_{t}=\alpha A, \\
& w_{t}=(1-\alpha) A k_{t} .
\end{aligned}
$$

\section{Capital Goods Sector}

Capital goods are produced by entrepreneurs. We shall think of entrepreneur- $j$, producing $K^{j}$, as the $j$-th capital good producing firm. As entrepreneurial generations are interconnected through a bequest motive, firm- $j$ is effectively an infinitely lived entity. At any point in time, the young member of entrepreneurial family- $j$ is the owner-manager of this firm, converting units of the final good into capital with a one-period lag.

The financial sector comes into play in determining how much investment each entrepreneur undertakes. In particular, if the entrepreneur invests $q^{j}>b^{j}$, she has to raise the deficit from the financial sector.

All entrepreneurs produce the same type of capital good and are price takers. The common return they earn from renting out their capital is $\rho$, the marginal product of capital in a competitive equilibrium and given by (2.5). For simplicity, we assume that capital goods fully depreciate upon use. 


\section{Cottage Industry Production}

Entrepreneurs also possess a technology whose output is not marketed and is entirely selfconsumed (household production). As in Banerjee and Newman (1993), we identify these entrepreneurs with self-sufficient peasants and cottage industries. Such home production is assumed not to be a part of the national income accounts.

Low-productivity cottage industry technology enables an entrepreneur to produce, with a one period lag, the same consumption good that the final goods sector manufactures:

$$
x_{t+1}=a b_{t}^{\delta}
$$

where $a>0$ and $\delta \in(0,1)$. The entrepreneur's choice of technology depends upon which one gives her a higher income and whether or not she is able to obtain external finance to operate the modern technology. We discuss this in details in the next section.

\subsection{The Moral Hazard Problem}

We motivate the existence of financial markets and intermediaries by introducing agency problems in firm borrowing. Specifically, following Holmstrom (1996) and Holmstrom and Tirole (1997), we allow an entrepreneur to choose between three types of investment projects. These projects differ in their probability of success and the amount of private benefit they bring to the entrepreneur.

Suppose the entrepreneur raises funds amounting to $q_{t}^{j}>b_{t}^{j}$ for her investment. When the project succeeds, it realizes a verifiable amount of capital,

$$
K_{t+1}^{j}=q_{t}^{j}
$$

But should it fail, it produces nothing.

The moral hazard problem arises from the fact that the probability of success depends on an unobserved action taken by the entrepreneur. The unobserved action can be interpreted as her choice on how to spend $q_{t}^{j}$. She can spend it on an efficient technology that results in success for sure, but uses up all of $q_{t}^{j}$. Or, she can spend it on one of two inefficient technologies that may not succeed. One of these technologies, a low moral hazard project, $\operatorname{costs} q_{t}^{j}-v q_{t}^{j}$, leaving $v q_{t}^{j}$ for the entrepreneur to appropriate. The other inefficient choice, a high moral-hazard project, costs $q_{t}^{j}-V q_{t}^{j}$ which leaves $V q_{t}^{j}$ in private benefits to the entrepreneur. Both inefficient technologies carry the same probability of success, $\pi$, but we assume that $0<v<V<1$. Hence, the entrepreneur clearly prefers the high moral-hazard project over the low moral-hazard one. ${ }^{9}$

\footnotetext{
${ }^{9}$ Note that entrepreneurs consume in the second period of their lives while they invest in the first period.
} 


\subsection{The Financial Sector}

The financial sector is a conduit transforming household savings into capital. Two types of agents participate on the supply side - financial intermediaries (banks) and households themselves.

Banks obtain their supply of loanable funds from households. Households have the choice of depositing their savings with banks, or lending directly to firms, or investing it on the international capital market. Direct lending to firms, which we shall refer to as direct (or market) finance, is made through the purchase of tradeable securities like corporate bonds and equities.

Capital is perfectly mobile across borders so that both households and entrepreneurs have free access to the international capital market. We analyze the case of a small open economy whose agents take the time-invariant (gross) world rate of return on investment, $R^{*}$, as given.

Absent any transactions costs or uncertainty in investment returns, ${ }^{10}$ households willingly hold both deposits and securities as long as they yield the same return, $R^{*}$. In other words, $R^{*}$ is the return that banks promise their depositors and also the guaranteed return on securities. ${ }^{11}$ Firms can borrow directly from households by agreeing to pay this return.

Compared to direct finance, indirect (or bank) finance plays a special role. In particular, banks are endowed with a monitoring technology that allows them to inspect a borrowing firm's cash flows and balance sheet, keep tabs on the owner-manager's activities and ensure the firm conforms to the terms agreed upon in the financial contract (Hellwig, 1991; Holmstrom and Tirole, 1997). Households do not possess this technology, or even if they do, are too disparate to effectively use it. Hence, banks assume the role of delegated monitors (Diamond, 1991).

Monitoring partially resolves the moral hazard problem and reduces the entrepreneur's opportunity cost of being diligent. As in Holmstrom (1996) and Holmstrom and Tirole

Since appropriation of investment resources is 'illegal', we assume that entrepreneurs cannot invest these on the financial market. Instead, all they can do is to hide them away for one period. Net return on such storage is zero, but storage activities are unobservable and cannot be penalized. Thus, although investors know for sure that the entrepreneur was not diligent when her investment project fails, they are unable to seize her stored goods.

${ }^{10}$ In equilibrium all entrepreneurs invest in the best project and behave diligently so that investment returns are guaranteed.

${ }^{11}$ Equities (claims to capital) are indistinguishable from bonds in this model. Households hold bonds and equities if they both yield $R^{*}$. A secondary market in securities does not exist since claims to capital are worthless after one period, the depreciation rate on capital being hundred percent. 
(1997), by choosing to monitor borrowers, banks are able to eliminate the high moral-hazard project but not the low moral-hazard one. For instance, a bank could simply veto the high moral-hazard project when it negotiates a loan contract with the firm. But such monitoring is privately costly for the bank and requires it to spend a nonverifiable amount $\gamma$ per unit invested by the entrepreneur. Hence, bank monitoring will be an optimal arrangement only if the gains from resolving agency problems outweigh the costs of monitoring firms.

\section{Optimal Contracts}

Whether or not an entrepreneur prefers to be diligent depends upon appropriate incentives and outside monitoring. Consider the financing options a generation- $t$ entrepreneur- $j$ faces when her desired investment size, $q_{t}$, exceeds her wealth, $b_{t}^{j}$. The entrepreneur may borrow the shortfall from two sources: directly from households and/or from banks.

Since banks monitor firms while households do not, we shall find it convenient to refer to the former as informed investors. We proceed to characterize optimal contracts when firms borrow from banks and/or the market. In both cases we are interested in an outcome where entrepreneurs behave diligently. In other words, we solve for contracts that always result in successful investment outcomes.

\subsection{Direct Finance}

In case of direct finance, an optimal contract between the firm and outside investors has a simple structure. Entrepreneurs will invest all internal funds, $b_{t}^{j}$, on their own project since they earn a strictly higher return on it than they would otherwise (see below). Households put up the remainder, $q_{t}-b_{t}^{j}$. Neither party is paid anything if the investment fails. When the project succeeds, the entrepreneur earns an amount $\theta_{t+1}^{E}>0$ while uninformed investors are paid $\theta_{t+1}^{U}>0$, where $\theta_{t+1}^{E}+\theta_{t+1}^{U}=\rho_{t+1} q_{t}$.

Entrepreneur- $j$ prefers to be diligent, that is, invests $q_{t}$ in the efficient technology as long as she earns an incentive compatible return:

$$
\theta_{t+1}^{E} \geq \pi \theta_{t+1}^{E}+V q_{t} \Rightarrow \theta_{t+1}^{E} \geq \frac{V}{1-\pi} q_{t}
$$

This, of course, implies that outside investors get paid at most $\theta_{t+1}^{U}=\left[\rho_{t+1}-V /(1-\pi)\right] q_{t}$. This is the pledgeable expected income that firms can credibly commit to their investors. The household participation constraint requires this income not to be lower than the amount that can be earned on the international capital market, $R^{*}\left[q_{t}-b_{t}^{j}\right]$. 
Hence, a necessary and sufficient condition for the entrepreneur to have access to direct finance is that

$$
\left[\rho_{t+1}-\frac{V}{1-\pi}\right] q_{t} \geq R^{*}\left[q_{t}-b_{t}^{j}\right] .
$$

Defining

$$
b_{t}^{H}\left(q_{t}\right) \equiv\left[1-\frac{1}{R^{*}}\left(\rho_{t+1}-\frac{V}{1-\pi}\right)\right] q_{t},
$$

we conclude that only entrepreneurs with $b_{t}^{j} \geq b_{t}^{H}\left(q_{t}\right)$ are able to obtain direct finance if they want to invest $q_{t}$.

\subsection{Indirect Finance}

For indirect or intermediated finance, there are three parties to the financial contract: the entrepreneur, the bank and uninformed investors.

As before, an optimal contract requires that no party earns anything when the project fails. When it succeeds, the total return, $\rho_{t+1} q_{t}$, is distributed such that $\theta_{t+1}^{E}+\theta_{t+1}^{U}+\theta_{t+1}^{B}=$ $\rho_{t+1} q_{t}$, with $\theta^{B}$ denoting the bank's returns.

If banks choose to monitor firms, a generation- $t$ entrepreneur's incentive constraint becomes

$$
\theta_{t+1}^{E} \geq \pi \theta_{t+1}^{E}+v q_{t} \Rightarrow \theta_{t+1}^{E} \geq \frac{v}{1-\pi} q_{t} .
$$

Monitoring occurs the same period that banks lend to firms. Banks have an incentive to monitor firms since it reduces the incentive compatible payoff that has to be committed to an entrepreneur, and thereby raises banking revenues. But monitoring is also costly and it reduces the total amount of loans a bank can make. We assume that banks discount monitoring costs at their opportunity cost, $R^{*}$. Banks are then willing to monitor only if they earn at least as much under monitoring as they would (in an expected sense) under no-monitoring

$$
\theta_{t+1}^{B}-R^{*} \gamma q_{t} \geq \pi \theta_{t+1}^{B} \Rightarrow \theta_{t+1}^{B} \geq \frac{R^{*} \gamma}{1-\pi} q_{t} .
$$

The pledgeable expected income in this case is

$$
\left[\rho_{t+1}-\frac{v+\gamma R^{*}}{1-\pi}\right] q_{t} .
$$

Let $L_{t}^{j}$ be the amount that a bank lends to entrepreneur- $j$. The bank's return from this entrepreneur is then

$$
\theta_{t+1}^{B, j}=R_{t+1}^{L} L_{t}^{j},
$$


where $R_{t+1}^{L}$ is the (gross) loan rate charged to borrowers. Note that the lending rate is the same across borrowers as both lenders and borrowers operate in competitive markets.

Since bank finance is relatively more expensive, entrepreneurs accept only the minimum amount necessary. From (3.4) this implies

$$
L_{t}^{j}\left(R_{t+1}^{L}, q_{t}\right)=\frac{\gamma R^{*}}{(1-\pi) R_{t+1}^{L}} q_{t}
$$

Uninformed investors must supply the balance $M_{t}^{j}=q_{t}-b_{t}^{j}-L_{t}^{j}$, whenever this amount is positive. Therefore, a necessary and sufficient condition for entrepreneur- $j$ to be financed is

$$
\left[\rho_{t+1}-\frac{v+\gamma R^{*}}{1-\pi}\right] q_{t} \geq R^{*}\left[q_{t}-b_{t}^{j}-L_{t}^{j}\right] .
$$

We can rewrite this condition as

$$
b_{t}^{j} \geq b_{t}^{L}\left(R_{t+1}^{L}, q_{t}\right) \equiv q_{t}-L_{t}^{j}\left(R_{t+1}^{L}, q_{t}\right)-\frac{q_{t}}{R^{*}}\left[\rho_{t+1}-\frac{v+\gamma R^{*}}{1-\pi}\right] .
$$

Only entrepreneurs with $b_{t}^{j} \geq b_{t}^{L}\left(R_{t+1}^{L}, q_{t}\right)$ are able to convince uninformed investors to supply enough funds for a project of size $q_{t}$.

\subsection{The Bank's Problem}

Given the loan demand $L_{t}^{j}$ from each borrowing firm $j$ from (3.5) above, the aggregate demand for bank loans is

$$
L_{t}=\int_{j \in E_{t}^{B}} L_{t}^{j} d G_{t}=\left[\frac{\gamma R^{*}}{(1-\pi) R_{t+1}^{L}}\right] \int_{j \in E_{t}^{B}} q_{t}^{j} d G_{t},
$$

where $E_{t}^{B} \subset E_{t}$ denotes the subset of firms borrowing from banks in period $t$. Hence, the total monitoring cost borne by the banking sector is

$$
\int_{j \in E_{t}^{B}} \gamma q_{t}^{j} d G_{t}=\frac{(1-\pi) R_{t+1}^{L} L_{t}}{R^{*}} .
$$

Let $D_{t}$ denotes the flow of deposits into the banking sector. Then banking profits in period- $(t+1)$ are given by

$$
\Pi_{t+1}^{B}=R_{t+1}^{L} L_{t}-R^{*} D_{t} .
$$

Banks face the resource constraint that total loans cannot exceed total deposits net of monitoring costs:

$$
L_{t} \leq D_{t}-\int_{j \in E_{t}^{B}} \gamma q_{t}^{j} d G_{t}
$$


The banking sector's optimization problem in period $t$ is to choose $L_{t}$ so as to maximize $\Pi_{t+1}^{B}$ subject to the constraints (3.3), (3.4) and (3.7).

Since bank profits are increasing in total loans, (3.7) holds with equality:

$$
L_{t}=D_{t}-\int_{j \in E_{B, t}} \gamma q_{t}^{j} d G_{t}=D_{t}-\left[\frac{(1-\pi) R_{t+1}^{L}}{R^{*}}\right] L_{t} .
$$

Moreover, in a competitive equilibrium, the banking sector earns zero profits. From (3.6) we then have

$$
R_{t+1}^{L} L_{t}=R^{*} D_{t}
$$

It follows from equations (3.8) and (3.9) that

$$
L_{t}=\pi D_{t},
$$

and

$$
R_{t+1}^{L}=\frac{R^{*}}{\pi}
$$

Hence, using (3.5), we observe that

$$
\phi_{t}^{j} \equiv \frac{L_{t}^{j}}{q_{t}}=\gamma\left(\frac{\pi}{1-\pi}\right) .
$$

In other words, for all $j \in E_{t}^{B}$, banks finance a fixed proportion of the firm's investment, irrespective of entrepreneur- $j$ specific characteristics, that is, $b_{t}^{j}$. Note that in order that the loan size does not exceed investment size, that is $\phi_{t}^{j} \leq 1$, monitoring costs should not be so high as to make it impossible for bank intermediation to resolve moral hazard problems. Hence, we restrict monitoring cost such that:

$$
\gamma \leq(1-\pi) / \pi
$$

Taking into account the optimal loan size (3.11), for any $q_{t}$, the lower wealth cut-off becomes

$$
b_{t}^{L}\left(q_{t}\right)=\left[1+\gamma-\frac{1}{R^{*}}\left(\rho_{t+1}+\frac{v}{1-\pi}\right)\right] q_{t} .
$$

It is natural to assume that $b_{t}^{H}\left(q_{t}\right) \geq b_{t}^{L}\left(q_{t}\right)$, or else there will be no demand for intermediation - monitoring would be too costly to be socially useful. From (3.2) and (3.12), we have $b_{t}^{H}\left(q_{t}\right) \geq b_{t}^{L}\left(q_{t}\right)$ as long as the expected gains from monitoring exceed its cost:

$$
\frac{V-v}{1-\pi} \geq \gamma R^{*}
$$




\subsection{Entrepreneur's Income under Optimal Contracts}

Denote entrepreneur- $j$ 's income in the second period of life by $z_{t+1}^{j}$. Each entrepreneur has the option of investing her funds on the domestic financial sector or lending abroad, both of which would earn her a gross return $R^{*}$.

Consider the case of an entrepreneur- $j$ who does not qualify for any external finance, that is, her internal funds are too small, $b_{t}^{j} \leq b_{t}^{L}\left(q_{t}\right)$. Clearly, she would prefer to engage in household production instead of lending out her funds iff

$$
a b_{t}^{\delta} \geq R^{*} b_{t} \Rightarrow b_{t} \leq \widehat{b}
$$

where, $\widehat{b} \equiv\left[a / R^{*}\right]^{1 /(1-\delta)}$. Her income is given by

$$
z_{t+1}^{j}= \begin{cases}a\left(b_{t}^{j}\right)^{\delta}, & b_{t}^{j} \in[0, \widehat{b}] \\ R^{*} b_{t}^{j}, & \left.b_{t}^{j} \in \widehat{[b}, b_{t}^{L}\right) .\end{cases}
$$

Next consider those who borrow both from the bank and the market, that is, $b_{t}^{j} \in$ $\left[b_{t}^{L}\left(q_{t}\right), b_{t}^{H}\left(q_{t}\right)\right)$. For these entrepreneurs, (3.10) and (3.11) imply that

$$
z_{t+1}^{j}=\rho_{t+1} q_{t}-R_{t+1}^{L} L_{t}^{j}-R^{*} M_{t}^{j}=\left[\rho_{t+1}-(1+\gamma) R^{*}\right] q_{t}+R^{*} b_{t}^{j}
$$

Note that these entrepreneurs earn a return strictly greater than what they would have earned by investing their wealth in the financial sector since $\rho_{t+1} \geq(1+\gamma) R^{*}{ }^{12}$

Finally, entrepreneurs with adequate internal funds, $b_{t}^{j} \geq b_{t}^{H}\left(q_{t}\right)$, who borrow only from the market, earn an income

$$
z_{t+1}^{j}=\rho_{t+1} q_{t}-R^{*}\left[q_{t}-b_{t}^{j}\right]=\left(\rho_{t+1}-R^{*}\right) q_{t}+R^{*} b_{t}^{j},
$$

which, again, exceeds the opportunity cost of internal funds.

We assume that parameters are such that $b_{t}^{L} \in(\tilde{b}, \hat{b})$ for any $q_{t}$. The lower bound, $\tilde{b}$, is given by

$$
\tilde{b}^{1-\delta} \equiv\left(\frac{a}{R^{*}}\right)\left[\frac{v /(1-\pi)}{v /(1-\pi)-\left[\alpha A-(1+\gamma) R^{*}\right]}\right],
$$

and ensures that income from modern sector activities exceeds that from household production. The upper bound ensures that a credit constrained entrepreneurial family does not prefer to invest its internal funds on the capital market rather than utilize it for household

\footnotetext{
${ }^{12}$ Since $\rho_{t+1} q_{t} \geq \theta_{t+1}^{B, j}=R_{t+1}^{L} L_{t}^{j}=[\gamma /(1-\pi)] R^{*} q_{t}, \rho_{t+1} \geq \pi \rho_{t+1}+\gamma R^{*}$. But, for the entrepreneur to agree to a bank loan, it must be true that $\rho_{t+1} \geq R_{t+1}^{L}$. It follows that $\rho_{t+1} \geq \pi R_{t+1}^{L}+\gamma R^{*}=R^{*}(1+\gamma)$.
} 
production. This latter restriction is imposed only to simplify accumulation of wealth among credit-constrained families. Entrepreneurial earnings are thus given by

$$
z_{t+1}^{j}\left(b_{t}^{j} \mid q_{t}\right)= \begin{cases}a\left(b_{t}^{j}\right)^{\delta}, & \text { if } b_{t}^{j} \in\left[0, b_{t}^{L}\left(q_{t}\right)\right), \\ {\left[\rho_{t+1}-(1+\gamma) R^{*}\right] q_{t}+R^{*} b_{t}^{j},} & \text { if } b_{t}^{j} \in\left[b_{t}^{L}\left(q_{t}\right), b_{t}^{H}\left(q_{t}\right)\right), \\ \left(\rho_{t+1}-R^{*}\right) q_{t}+R^{*} b_{t}^{j}, & \text { if } b_{t}^{j} \in\left[b_{t}^{H}\left(q_{t}\right), \infty\right) .\end{cases}
$$

We summarize properties of optimal loan contracts and external financing choices in Proposition 1 below:

Proposition 1: Given $q_{t}>b_{t}^{j}$ and the wealth distribution $G_{t}(b)$,

(i) Entrepreneurs with $b_{t}^{j}<b^{L}\left(q_{t}\right)$ are unable to obtain any external finance and operate traditional production technologies;

(ii) Entrepreneurs with $b_{t}^{j} \in\left[b^{L}\left(q_{t}\right), b^{H}\left(q_{t}\right)\right)$ obtain external finance from banks as well as households: they borrow $\phi q_{t}$ from banks at the loan rate $R_{t+1}^{L}$, given by (3.10) and (3.11) above, agree to being monitored, and raise the remaining $(1-\phi) q_{t}-b_{t}^{j}$ directly from households at the rate $R^{*}$; optimal loan contracts guarantee these entrepreneurs incentive compatible payments such that they behave diligently;

(iii) Entrepreneurs with $b_{t}^{j} \geq b^{H}\left(q_{t}\right)$ borrow only from households, paying them a return of $R^{*}$; once again, incentive compatible payments to these entrepreneurs ensure that investments succeed for sure;

(iv) Entrepreneurial income in each case is given by (3.14) above.

\section{Investment Choice and Financial Structure}

So far we have characterized financial contracts and returns for an arbitrary investment of $q_{t}$. We now turn to the entrepreneur's investment decision.

Recall that entrepreneurs may operate either of two types of production technologies: a modern-sector or a cottage-industry technology. A distinguishing feature of developing countries is their dualistic structure, the coexistence of a labor-intensive low-productivity sector with a high-productivity modern sector specializing in factory goods.

A number of commentators have suggested that entry into such modern-sector activities require large setup costs. ${ }^{13}$ These include fixed capital requirements and costs of adapting

\footnotetext{
${ }^{13}$ The industrial revolution was possible, according to Hicks (1969) and North (1981), because financial markets enabled England to implement newer technologies. In many cases, these technologies were invented early on but large-scale investment requirements hampered their implementation.
} 
newer types of technologies. The efficacy of a financial system lies in the degree to which it allows entrepreneurs to surmount such lumpy investment requirements. To capture this notion, we impose a minimum investment size of $q^{*}$ on any entrepreneur wishing to produce capital goods. We allow entrepreneurs to choose as much as they want to invest as long as they are able to invest this minimum amount.

\subsection{Minimum Investment Size}

The proportion of entrepreneurs who enter the modern sector is endogenous and determined by their access to outside finance. The minimum investment size $q^{*}$ defines a minimum amount of initial wealth (internal funds), $b_{t}^{*}$, that an entrepreneur needs to qualify for external finance. From (2.5) and (3.12), this constraint is given by

$$
b_{t}^{*}=\frac{q^{*}}{R^{*}}\left[\frac{v}{1-\pi}-\left[\alpha A-(1+\gamma) R^{*}\right]\right] .
$$

Since this expression does not involve any time dependent variables, we shall denote it by $b_{L}^{*}$ from now on.

A credit-rationed entrepreneur- $j\left(b_{t}^{j}<b_{L}^{*}\right)$ earns $z_{t+1}^{j}=a\left(b_{t}^{j}\right)^{\delta}$ from cottage-industry production and bequeaths a $(1-\beta)$ fraction of this income. Asset accumulation for such firms is given by

$$
b_{t+1}^{j}=(1-\beta) a\left(b_{t}^{j}\right)^{\delta} .
$$

It follows that the steady-state wealth level of credit-constrained entrepreneurial families is

$$
b_{C}=[a(1-\beta)]^{1 /(1-\delta)}
$$

We assume that $b_{C}<b_{L}^{*}$, that is,

$$
[a(1-\beta)]^{1 /(1-\delta)}<\frac{q^{*}}{R^{*}}\left[\frac{v}{1-\pi}-\left[\alpha A-(1+\gamma) R^{*}\right]\right] .
$$

Assumption 3 is satisfied under intuitively plausible conditions: when productivity of traditional activities $(a)$ is too low, when the fixed cost of entering the modern sector $\left(q^{*}\right)$ is too high, or when monitoring costs $(\gamma)$ are high. As long as this assumption is satisfied, for all $b_{t}^{j} \in\left[0, b_{L}^{*}\right)$,

$$
b_{t+1}^{j}<b_{L}^{*} \forall t, \text { and } \lim _{t \rightarrow \infty} b_{t+1}^{j}=b_{C} .
$$

Following our notation, $G_{0}\left(b_{L}^{*}\right)$ indicates the fraction of generation-0 entrepreneurs with assets less than $b_{L}^{*}$. Thus, we conclude: 
Proposition 2: Given $\left(\gamma, v, V, R^{*}\right)$, the initial wealth distribution, $G_{0}(b)$, determines which of the entrepreneurial families participate in the modern sector. A constant proportion of them, given by $G_{0}\left(b_{L}^{*}\right)$, are never able to obtain external finance, engaging in traditional sector activities instead. In the long run, wealth of these credit-constrained entrepreneurial families converges to the steady-state level $b_{C}$ given by (4.2) above.

\subsection{Optimal Investment Decision}

Entrepreneurs whose initial wealth exceeds the cutoff level $b_{L}^{*}$ qualify for outside financing. It will be convenient to illustrate their investment decision graphically using Figure 1.

Given optimal contracts and financing arrangements for investment $q_{t}$, the optimal investment size $q_{t}$ is chosen by an entrepreneur to maximize her income. Recall that for investment size $q_{t}$, the minimum amount of internal funds required to qualify for indirect and direct finance are,

$$
\begin{aligned}
b^{L}\left(q_{t}\right) & =\frac{q_{t}}{R^{*}}\left[\frac{v}{1-\pi}-\left[\alpha A-(1+\gamma) R^{*}\right]\right], \text { and } \\
b^{H}\left(q_{t}\right) & =\frac{q_{t}}{R^{*}}\left[\frac{V}{1-\pi}-\left(\alpha A-R^{*}\right)\right]
\end{aligned}
$$

respectively, ${ }^{14}$ where we have substituted for the equilibrium rental on capital, (2.5).

These cut-off wealth levels are shown in Figure 1 as two rays passing through the origin. Since $b^{H}\left(q_{t}\right)>b^{L}\left(q_{t}\right)$ for any $q_{t}$ (by Assumption 2), the $b^{H}\left(q_{t}\right)$ line is steeper than $b^{L}\left(q_{t}\right)$. The intersection points of these rays with $q^{*}$ are labeled $b_{H}^{*}$ and $b_{L}^{*}$ respectively.

Suppressing the $j$-superscript, consider a generation- $t$ entrepreneur with inherited bequest level $b_{t}>b_{L}^{*}$. Note that this $b_{L}^{*}$ is the same as (4.1), obtained by substituting $q_{t}=q^{*}$ into (4.3). In Figures 1(a) and 1(b), $q_{I, t}$ and $q_{U, t}$ are given by the points of intersection of $b^{L}\left(q_{t}\right)$ and $b^{H}\left(q_{t}\right)$ with the entrepreneur's wealth, $b_{t}$.

Observe that $b_{t}<b^{L}\left(q_{t}\right)$ for any $q_{t}>q_{I, t}$. Such an entrepreneur desiring to invest more than $q_{I, t}$ cannot convince uninformed investors to supply enough funds for her project, and is completely rationed from the credit market. She can only resort to household production in that case and earn an income $z_{t+1}=a b_{t}^{\delta}$ (from (3.14)). This earning is given by the horizontal line PQ in Figures 1(a) and $(b)$.

Similarly, $b^{L}\left(q_{t}\right) \leq b_{t}<b^{H}\left(q_{t}\right)$ for any $q_{U, t}<q_{t} \leq q_{I, t}$. If this entrepreneur chooses an investment size in this range, she can convince uninformed investors to fund her project only if she simultaneously borrows from the bank. Her earning is then $z_{t+1}=R^{*} b_{t}+$

\footnotetext{
${ }^{14}$ Assumptions 4 and 5 (next section) guarantee that $b^{L}\left(q_{t}\right)>0$ and $b^{H}\left(q_{t}\right)>0$ for any $q_{t}$.
} 
$\left[\alpha A-(1+\gamma) R^{*}\right] q_{t}$, shown by the flatter line $\mathbf{H N}$ with intercept $R^{*} b_{t}$ in Figures $1(a)$ and $(b)$.

Finally, for any $q^{*} \leq q_{t} \leq q_{U, t}, b_{t} \geq b^{H}\left(q_{t}\right)$. An entrepreneur can fund an investment in this range by raising funds directly from the market without requiring any bank finance. His earning $z_{t+1}=R^{*} b_{t}+\left[\alpha A-R^{*}\right] q_{t}$ is the steeper line $\mathbf{E F}$ with intercept $R^{*} b_{t}$ in Figures $1(a)$ and $(b)$.

To summarize, when an entrepreneur chooses her level of investment, her earnings are given as:

$$
z_{t+1}\left(q_{t} \mid b_{t}\right)= \begin{cases}R^{*} b_{t}+q_{t}\left(\alpha A-R^{*}\right), & \text { if } q_{t} \in\left[q^{*}, q_{U, t}\right] \\ R^{*} b_{t}+q_{t}\left[\alpha A-(1+\gamma) R^{*}\right], & \text { if } q_{t} \in\left(q_{U, t}, q_{I, t}\right] \\ a b_{t}^{\delta}, & \text { if } q_{t} \in\left(q_{I, t}, \infty\right) .\end{cases}
$$

An entrepreneur chooses $q_{t}$ so as to maximize $z_{t+1}\left(q_{t}\right)$. Solving this optimization problem is straightforward from Figure 1.

Income $z_{t+1}\left(q_{t}\right)$ is given by the piecewise linear schedule EF, HN and PQ. Two possibilities arise: $q_{I, t}$ is the investment choice when the height of the point $\mathbf{N}$ is greater than that of the point $\mathbf{F}$ [Figure 1(a)], whereas $q_{U, t}$ is chosen when the opposite holds [Figure 1(b)]. ${ }^{15}$

Closed-form solutions for these investment levels can be obtained using (4.3) and (4.4). In particular, $q_{I, t}$ is the solution to the equation $b_{t}=b^{L}\left(q_{t}\right)$ so that

$$
q_{I, t}=\left[\frac{R^{*}}{v /(1-\pi)-\left[\alpha A-(1+\gamma) R^{*}\right]}\right] b_{t} .
$$

Similarly, $q_{U, t}$ solves $b_{t}=b^{H}\left(q_{t}\right)$ which gives us

$$
q_{U, t}=\left[\frac{R^{*}}{V /(1-\pi)-\left(\alpha A-R^{*}\right)}\right] b_{t} .
$$

Since $z_{t+1}\left(q_{t}\right)$ is strictly increasing in the range $q_{t} \in\left[q^{*}, q_{U, t}\right]$, maximal earning occurs at $q_{t}=q_{U, t}$ and is given by

$$
z_{t+1}\left(q_{U, t}\right)=\left[\frac{[V /(1-\pi)] R^{*}}{V /(1-\pi)-\left(\alpha A-R^{*}\right)}\right] b_{t} .
$$

Likewise, since $z_{t+1}\left(q_{t}\right)$ is strictly increasing in the range $q_{t} \in\left(q_{U, t}, q_{I, t}\right]$, the maximum earning in this range occurs at $q_{t}=q_{I, t}$, and the maximum earning is

$$
z_{t+1}\left(q_{I, t}\right)=\left[\frac{[v /(1-\pi)] R^{*}}{v /(1-\pi)-\left[\alpha A-(1+\gamma) R^{*}\right]}\right] b_{t}
$$

\footnotetext{
${ }^{15}$ In Figure 1(a), $q_{I, B}$ denotes bank borrowing, $q_{I, M}$ denotes market borrowing and $q_{I, S}$ denotes selffinancing in a bank-based system. Similarly for a market-based system in Figure 1(b).
} 
It follows that an entrepreneur chooses $q_{I, t}$ over $q_{U, t}$ iff,

$$
\begin{aligned}
z_{t+1}\left(q_{I, t}\right) & \geq z_{t+1}\left(q_{U, t}\right) \\
& \Leftrightarrow \frac{\alpha A-(1+\gamma) R^{*}}{v} \geq \frac{\alpha A-R^{*}}{V},
\end{aligned}
$$

a condition that does not depend upon borrower characteristics, that is, on $b_{t}$. Note that incentive constraints of all modern-sector entrepreneurs are binding, since $q_{I, t}\left(q_{U, t}\right)$ is given by the intersection of $b_{t}$ with $b^{L}\left(q_{t}\right)\left[b^{H}\left(q_{t}\right)\right]$.

\subsection{Implications for Financial System}

Consider now the financial system resulting from firm-financing decisions. As long as (4.9) holds [Figure 1(a)], except for the fraction $G_{0}\left(b_{L}^{*}\right)$ of entrepreneurs who are creditconstrained, all capital goods producers finance their investment through a mix of intermediated and unintermediated finance. We label this a bank-based financial system.

On the other hand, if (4.9) does not hold [Figure 1(b)], unconstrained entrepreneurs earn a higher income with purely unintermediated finance. Despite this, one group of entrepreneurial families have to rely upon bank-finance, at least in the short-run. To see this, consider entrepreneurs with $b_{L}^{*} \leq b_{t}<b_{H}^{*}$. If we were to redraw $q_{U, t}$ and $q_{I, t}$ for such an entrepreneur, we would have $q_{U, t}<q^{*}<q_{I, t}$. Since (4.9) is not satisfied, this entrepreneur's earning would be maximized for investment level $q_{U, t}$. But that level of investment would not be permissible since $q_{U, t}<q^{*}$. Under the circumstances, this entrepreneur will have to choose an investment $q_{I, t}$. Thus, all entrepreneurs in the range $b_{t} \in\left[b_{L}^{*}, b_{H}^{*}\right)$ have to rely upon mixed finance, whereas those who are wealthy enough $\left(b_{t} \geq b_{H}^{*}\right)$ use only market finance.

This reliance on mixed finance is, however, temporary. Since the wealth of these entrepreneurial families grow at the rate of $g_{I}$, they eventually cross $b_{H}^{*}$. Thereafter, they too choose only market finance, growing at the rate $g_{U}$ (see next section for details). In the long-run, all entrepreneurs with $b_{t} \geq b_{L}^{*}$ use only unintermediated finance in Figure 1(b). We shall call this a market-based system.

Depending on parameter values, both intermediated or bank-based and market-based financial systems may thus emerge. Rewriting condition (4.9), the following proposition summarizes this important result: 
Proposition 3: The financial structure of an economy is bank-based if and only if

$$
1-\frac{\gamma R^{*}}{\alpha A-R^{*}} \geq \frac{v}{V}
$$

It is otherwise market-based without any dependence on intermediated finance in the longrun. In the short-run, some entrepreneurs with low wealth rely upon intermediated finance even in a market-based system.

Intuitively, the financial structure is likely to be bank-based whenever the cost of monitoring $(\gamma)$ is low and whenever the residual moral hazard problem under bank monitoring $(v)$ is low relative to the moral hazard problem in the absence of any external monitoring $(V){ }^{16}$

\section{Dynamic Equilibria}

Long-run equilibria in a standard overlapping generations economy with $A k$ technology are known to be balanced growth paths where per capita quantities grow at the same constant rate, while prices remain constant.

The two modifications we have introduced here are moral hazard in the loanable funds market and sector-specific investment choices. Dynamic equilibria in this modified economy are now characterized by constant growth rates of GDP (GNP), capital stock and consumption per worker. Since the composition of population is constant, GDP (GNP) and capital per capita also grow at this same rate, but consumption per capita does not. ${ }^{17}$ In particular, household and modern-sector entrepreneurial consumption grow at the same rate, but traditional-sector consumption does not: income levels of the two entrepreneurial classes diverge along the balanced-growth path.

\section{Wealth Accumulation}

To see this, let us begin by looking at wealth accumulation. Consider first an environment where a bank-based system (mixed finance) is the preferred regime. For entrepreneur- $j$ who is not credit-constrained $\left(b_{t}^{j} \geq b_{L}^{*}\right)$, combining (2.2) and (4.8) gives us

$$
\begin{aligned}
b_{t+1}^{j} & =(1-\beta) z_{t+1}^{j}\left(q_{I, t}^{j}\right) \\
& =(1-\beta)\left[\frac{[v /(1-\pi)] R^{*}}{v /(1-\pi)-\left[\alpha A-(1+\gamma) R^{*}\right]}\right] b_{t}^{j} .
\end{aligned}
$$

\footnotetext{
${ }^{16}$ Similar results obtain when we allow for $R$ to be endogenously determined in a closed-economy setting. Details available upon request.

${ }^{17}$ If GDP were to take into account household production, per capita GDP would grow at a slower rate. Note also that since the depreciation rate is $100 \%$, the economy immediately jumps to this growth path.
} 
Thus, for an unconstrained entrepreneur- $j$,

$$
b_{t+1}^{j}=\left(1+g_{I}\right) b_{t}^{j},
$$

so that assets of firm- $j$ (entrepreneurial family- $j$ ) grow at the constant rate $g_{I}$. The growth rate $g_{I}$ is defined by ${ }^{18}$

$$
1+g_{I} \equiv(1-\beta)\left[\frac{\{v /(1-\pi)\} R^{*}}{v /(1-\pi)-\left\{\alpha A-(1+\gamma) R^{*}\right\}}\right] .
$$

Likewise, a market-based financial regime leads to

$$
b_{t+1}^{j}=\left(1+g_{U}\right) b_{t}^{j}
$$

for an unconstrained entrepreneur- $j$. Here the $j$-th entrepreneurial family's assets grow at the rate $g_{U}$, where ${ }^{19}$

$$
1+g_{U} \equiv(1-\beta)\left[\frac{\{V /(1-\pi)\} R^{*}}{\{V /(1-\pi)\}-\left(\alpha A-R^{*}\right)}\right] .
$$

\section{Capital Accumulation}

Optimal investment choices are linear in entrepreneurial wealth as equations (4.5) and (4.6) show. To determine the rate of capital accumulation, consider again a bank-based regime.

The total stock of capital produced at date- $(t+1)$ depends upon the volume of investment undertaken at date- $t$. Define

$$
\bar{q}_{I, t} \equiv \int_{b_{L}^{*}}^{\infty} q_{I, t}^{j} d G_{t}, \quad \bar{b}_{t} \equiv \int_{b_{L}^{*}}^{\infty} b_{t}^{j} d G_{t} .
$$

Optimal loan contracts ensure that every entrepreneur works diligently in equilibrium. Using (2.7), total (and per capita) capital goods produced in a bank-based system is

$$
\begin{aligned}
K_{I, t+1} & =k_{I, t+1}=\bar{q}_{I, t} \\
& =\left[\frac{R^{*}}{v /(1-\pi)-\left[\alpha A-(1+\gamma) R^{*}\right]}\right] \bar{b}_{t} .
\end{aligned}
$$

${ }^{18}$ In Appendix A.1 we check that this growth rate is positive when

$$
\left[\alpha A-R^{*}(1+\gamma)\right] \leq \frac{v}{1-\pi} \leq\left[\alpha A-R^{*}(1+\gamma)\right] /\left[1-(1-\beta) R^{*}\right]
$$

(Assumption 4)

${ }^{19}$ Once again, the growth rate is positive if

$$
\left(\alpha A-R^{*}\right) \leq \frac{V}{1-\pi} \leq\left[\alpha A-R^{*}\right] /\left[1-(1-\beta) R^{*}\right] .
$$

(Assumption 5) 
Recall that the measure of entrepreneurs who qualify for loans does not change over time since return on savings, and hence $b_{L}^{*}$, are time-invariant. Using (5.1) we obtain

$$
\begin{aligned}
k_{I, t+1} & =\left[\frac{R^{*}}{v /(1-\pi)-\left[\alpha A-(1+\gamma) R^{*}\right]}\right]\left(1+g_{I}\right) \bar{b}_{t-1} \\
& =\left(1+g_{I}\right) \bar{q}_{I, t-1} \\
& =\left(1+g_{I}\right) k_{I, t},
\end{aligned}
$$

so that capital per capita grows at the same rate as entrepreneurial wealth.

Similarly, when unintermediated finance is chosen, per capita capital grows at the rate $g_{U}:$

$$
k_{U, t+1}=\left(1+g_{U}\right) k_{U, t} .
$$

\section{GDP, GNP and Consumption Growth}

Since the aggregate production function is linear in capital, growth of GDP per capita mimics that of capital. In other words, for a country that chooses a bank-based financial system

$$
y_{I, t+1}=\left(1+g_{I}\right) y_{I, t},
$$

whereas for market-based system

$$
y_{U, t+1}=\left(1+g_{U}\right) y_{U, t} .
$$

However, given our small open-economy assumption with perfect capital mobility, a more appropriate measure of income is GNP. Suppose that households supply their savings to the domestic financial sector first, and then invest any excess on the international capital market. Similarly, the domestic financial sector first relies on the domestic loanable funds market before approaching the international capital market. Since banks and entrepreneurs pay the world rate of return, $R^{*}$, the loan market always clears.

Consider first a bank-based system. Demand for loanable funds comes from banks seeking deposits $\left(D_{t}\right)$ and from entrepreneurs seeking direct finance $\left(M_{t}\right)$. It is given by

$$
\begin{aligned}
D_{t}+M_{t} & =\frac{L_{t}}{\pi}+M_{t} \\
& =\frac{\phi}{\pi} \int_{b_{L}^{*}}^{\infty} q_{I, t}^{j} d G_{t}+\int_{b_{L}^{*}}^{\infty}\left[(1-\phi) q_{I, t}^{j}-b_{t}^{j}\right] d G_{t} \\
& =(1+\gamma) k_{I, t+1}-\bar{b}_{t},
\end{aligned}
$$

where the last step follows from (3.11). Supply of loanable funds, on the other hand, comes from household savings, $S_{t}$. Noting that the measure of households is unity and that they 
save their entire wage income, the equilibrium wage rate from (2.5) gives us

$$
S_{t}=(1-\alpha) A k_{I, t}
$$

Net lending abroad (NLA) by households is then ${ }^{20}$

$$
N L A_{I, t}=S_{t}-D_{t}-M_{t}=(1-\alpha) A k_{I, t}+\bar{b}_{t}-(1+\gamma) k_{I, t+1} .
$$

Thus, after financing new investments and spending resources in bank monitoring, the remainder of investable resources (household savings plus entrepreneurial wealth) is invested on the international capital market.

Current loans made abroad yield a flow of net interest income from abroad (NIA) the following period. This is given by

$$
N I A_{I, t+1}=R^{*}\left[(1-\alpha) A k_{I, t}+\bar{b}_{t}-(1+\gamma) k_{I, t+1}\right]
$$

Clearly, NIA grows at the rate $g_{I}$, since

$$
\begin{aligned}
N I A_{I, t+1} & =\left(1+g_{I}\right) R^{*}\left[(1-\alpha) A k_{I, t-1}+\bar{b}_{t-1}-(1+\gamma) k_{I, t}\right] \\
& =\left(1+g_{I}\right) N I A_{I, t} .
\end{aligned}
$$

GNP in this economy is simply the sum of GDP and net interest income from abroad. Therefore it too grows at the rate of growth of GDP:

$$
G N P_{I, t+1}=y_{I, t+1}+N I A_{I, t+1}=\left(1+g_{I}\right)\left[y_{I, t}+N I A_{I, t}\right]=\left(1+g_{I}\right) G N P_{I, t} .
$$

Similarly, under a market-based system, net loans abroad (NLA) are

$$
N L A_{U, t}=S_{t}-M_{t}=(1-\alpha) A k_{U, t}+\bar{b}_{t}-k_{U, t+1}
$$

so that

$$
\begin{aligned}
N I A_{U, t+1} & =\left(1+g_{U}\right) N I A_{U, t}, \\
\text { and } \quad G N P_{U, t+1} & =\left(1+g_{U}\right) G N P_{U, t} .
\end{aligned}
$$

Consider now consumption paths for different types of agents. The equilibrium wage rate is linear in capital, from (2.5), while second-period consumption of households is equal to $R^{*} w_{t}$. Hence, per capita household consumption grows at the rate of growth of the capital stock. It is equal to, $g_{I}$ or $g_{U}$, depending upon the prevailing financial structure.

Among entrepreneurs, however, access to finance makes a difference on their consumption and wealth profiles. A fraction $G_{0}\left(b_{L}^{*}\right)$ of them do not qualify for loans and cannot enter

\footnotetext{
${ }^{20}$ We are assuming, without loss of generality, that this amount is positive.
} 
the modern-sector. They engage, instead, in low-productivity cottage industry, or household production. In the long-run, wealth of all these credit-constrained entrepreneurial families converges to the steady-state,

$$
b_{C}=[a(1-\beta)]^{1 /(1-\delta)}
$$

Consequently, their per capita consumption also converges to the steady-state value, $\beta a\left(b_{C}\right)^{\delta}$.

For all other entrepreneurs, access to external finance ensures that their per capita consumption grows at the rate of growth of their wealth, $g_{I}$ or $g_{U}$. As a result, consumption and wealth inequality among the two types of entrepreneurs rise along the balanced-growth path.

We collect these results in Proposition 4 below.

Proposition 4: Along the long-run growth path,

(i) Per capita GDP, GNP and capital grow at the constant rate $g_{i}$ given by (5.2) and (5.4) above, where $i \in\{I, U\}$ denotes the financial system in place as outlined by Proposition 3;

(ii) A proportion $1-G_{0}\left(b_{L}^{*}\right)$ of entrepreneurial families, with initial wealth $b_{0}^{j} \geq b_{L}^{*}$, produce capital goods in the modern sector, and enjoy sustained consumption and wealth improvements at the rate $g_{i}$;

(iii) The remaining $G_{0}\left(b_{L}^{*}\right)$ proportion of entrepreneurial families, with initial wealth $b_{0}^{j}<$ $b_{L}^{*}$, engage in household production, their wealth converging to $b_{C}$ given by (4.2) above, and consumption level converging to $\beta a\left(b_{C}\right)^{\delta}$; and

(iv) Consumption levels among successive generations of households increase at the constant rate $g_{i}$.

\section{Discussion and Policy Considerations}

Our analysis has a number of implications for the "banks versus market" debate, as also for the efficacy of credit markets in transforming traditional economies into modern manufacturing ones.

\section{Growth Rates and the Quality of Institutions}

A key result we obtain entails that an economy's growth rate depends upon the quality of its institutions entrusted with resolving agency problems. 
We view the moral hazard problem $(v, V)$, and the cost of controlling it $(\gamma)$, as primarily institutional. These parameters impact the economy's growth rate since they determine the nature and magnitude of agency costs. Expressions for growth rates in (5.2) and (5.4) imply that $\partial g_{I} / \partial \gamma<0, \partial g_{I} / \partial v<0$, and $\partial g_{U} / \partial V<0$. Faster growth results, therefore, when $\gamma$ or $v$ is lower in a bank-based system, and when $V$ is lower in a market-based one.

What explains cross-national differences in these cost parameters? The answer must lie, in part, in the quality of legal and financial institutions. Poorly developed systems that lack transparency in book-keeping, use archaic accounting and bankruptcy procedures, and promote corruption, intensify agency problems by making it easier for firms to obfuscate their activities. They may also increase the cost of monitoring by making contracts harder to enforce.

Even when technology $(\alpha, A)$ is identical across countries using similar financial institutions, their growth rates need not be identical. A less efficient financial system in one country (that is, higher $\gamma, v$ or $V$ ), would frustrate its ability to resolve agency problems and smoothly convert savings into investment. Lower growth would result. ${ }^{21}$

The quality of services that a financial system provides is, thus, a fundamental determinant of growth. This 'legal-based' view has been recently espoused by LaPorta et al. (1997, 1998) in their study of legal rules that protect corporate shareholders and creditors. Its relevance in explaining the cross-country growth experience is confirmed by Levine's (2000) study of 48 countries.

\section{Banks versus Markets}

Our analysis sheds light on the long-standing debate whether bank-based or marketbased systems are better for growth. It suggests that such an 'either-or' question is, in fact, ill-posed: the growth rate is a function not so much of the chosen financial regime as of the quality of services it delivers.

It is, indeed, possible for two countries to have different financial systems but enjoy similar growth rates. Consider two countries characterized by the vectors $\left(v_{\ell}, \gamma_{\ell}, V_{\ell}\right), \ell=1,2$. Suppose also that country 1 has a bank-based regime while country 2 has a market-based one. Following Proposition 3, these financial regimes will be in place as long as

$$
\text { and } \quad \begin{aligned}
\frac{\alpha A-R^{*}\left(1+\gamma_{1}\right)}{v_{1}} & \geq \frac{\alpha A-R^{*}}{V_{1}}, \\
v_{2} & \leq \frac{\alpha A-R^{*}}{V_{2}},
\end{aligned}
$$

\footnotetext{
${ }^{21}$ This also implies that growth takeovers are possible - poorer countries may ultimately surpass richer ones if they invest in better financial institutions.
} 
hold.

These conditions, on their own, imply little about growth rates in one country versus another. Given the same $\left(\alpha, A, R^{*}\right)$, if cost parameters $\left(v_{1}, \gamma_{1}, V_{2}\right)$ are such that

$$
\left[\alpha A-R^{*}\left(1+\gamma_{1}\right)\right] / v_{1}=\left(\alpha A-R^{*}\right) / V_{2}
$$

growth rates in the two countries will be similar, $g_{1}=g_{2} \cdot{ }^{22}$ If, on the other hand,

$$
\left[\alpha A-R^{*}\left(1+\gamma_{1}\right)\right] / v_{1}<\left(\alpha A-R^{*}\right) / V_{2}
$$

country 1 will grow at a slower rate, $g_{1}<g_{2}$. This happens not because the country uses a bank-based system, but rather because its banking sector is inefficient in allocating resources. It is not possible, then, to attribute faster growth in one country over another purely to its choice of financial regime without explicitly taking into account the efficiency of that financial regime. This squares well with Levine's (2000) cross-country findings that the type of financial system does not seem to matter much for economic growth.

Note, moreover, that endogenously evolved financial systems are also growth maximizing here. Recall that a bank-based system is preferred over a market-based one only if entrepreneurs prefer mixed-finance over purely market-finance, that is, if condition (4.9) holds. Under a bank-based system, the country grows at the rate given by (5.2). Had a market-based system prevailed instead, the growth rate would have been given by (5.4).

When an economy endogenously chooses a bank-based system, condition (4.9) guarantees that $g_{I} \geq g_{U}$. That is, a particular country that chooses a bank-based system grows faster than it would under the alternative system. Therefore, a policy of promoting one type of financial arrangement over another, say a market-based system over an existing bank-based one, may be misplaced and fail to raise economic growth.

One way to promote market-finance over bank-finance would be to reduce $V$ through appropriate policies. Marginal changes in $V$ do not alter the cost of funds in a bank-based system which depends only upon $v$ and $\gamma$. It is only when $V$ is reduced substantially to overturn the condition outlined in Proposition 3, that growth improves. A market-based system would endogenously evolve in that case; growth would also be faster compared to before [by (4.9)].

\section{Level Effects of Bank-based Systems}

Despite neither system being especially better for faster growth, bank-based systems have an edge over market-based ones along other dimensions. In particular, a bank-based economy

\footnotetext{
${ }^{22}$ From equations (5.2) and (5.4), $1+g_{1}=(1-\beta) R^{*} /\left[1-\left\{\alpha A-\left(1+\gamma_{1}\right) R^{*}\right\} /\left\{v_{1} /(1-\pi)\right\}\right]$, and $1+g_{2}=$ $(1-\beta) R^{*} /\left[1-\left(\alpha A-R^{*}\right) /\left\{V_{2} /(1-\pi)\right\}\right]$, so that $g_{1} \gtreqless g_{2}$ whenever $\left[\alpha A-R^{*}\left(1+\gamma_{1}\right)\right] / v_{1} \gtreqless\left(\alpha A-R^{*}\right) / V_{2}$.
} 
undertakes a higher level of investment than a market-based one with similar growth rate. The size of the modern-sector is also larger in a bank-based system.

Consider our previous example of countries 1 and 2 and suppose both countries are growing at identical rates, $g_{1}=g_{2}$. Appendix A.2 shows that even if wealth distributions are identical in the two countries, investment size for all modern-sector entrepreneurs is strictly greater under a bank-based regime, that is, in country 1. One implication is that country 1 will have a permanently higher level of per capita GDP than country 2, as long as both economies start out with the same wealth distribution.

Similarly, in Appendix A.3 we show that the minimum wealth, $b_{L}^{*}$, that entrepreneurs require to engage in manufacturing activities is smaller in country 1. Given identical wealth distributions in the two economies, the size of the traditional sector is then smaller in country 1. More entrepreneurs supply capital in this economy, so that GDP per capita is again higher than in country 2. A bank-based system is, hence, more conducive for the process of industrialization which shifts production from traditional activities to ones involving manufacturing and marketed output.

These level effects of a bank-based system both result because banks monitor firms and reduce incentive problems, while markets are more 'hands-off' in their lending activities. Bank monitoring effectively substitutes for entrepreneurial wealth, but cannot do so entirely since monitoring does not completely eliminate the agency problem.

But market finance need not play such a passive role in resolving agency problems. It has been argued (see, for instance, Allen and Gale, 2000; Scharfstein, 1988) that for some types of market finance, especially equity, shareholder rights may substitute for the monitoring role played by financial intermediaries. Aggressive shareholder voting rights in the US, in particular, are cited as having been historically important in ensuring that owner-managers do not stray too far from their investors' interests.

Since we do not take into account possible monitoring by shareholders, our model cannot handle this directly although one way to incorporate better shareholder rights is through a lower $V$. Our analysis of market finance is, therefore, better-suited for tradeable securities like bonds that are essentially arms length lending, with little involvement in firm's day-today activities. In any case, as Allen and Gale (2000) point out, capital markets in developing countries tend to be dominated more by debt securities than equities. Even when equity markets are well-developed, there are often limits on how effectively shareholders can exercise their rights in overthrowing poorly-performing managers. 


\section{Effect of Institutional Reforms}

While policy interventions, under either type of financial regime, affect growth rates, these have to be targeted towards improving the quality of services that the existing system uses. But bank-based and market-based systems react somewhat differently to such interventions.

Consider the effect of reducing the monitoring cost, $\gamma$ (analysis same for $v$ ), on a bankbased economy, perhaps through better contract enforcements. Lower $\gamma$ would lead to greater borrowing and higher investment by all entrepreneurs [by (4.5)]. Since the investment rate has a growth effect in the $A k$-model, lower monitoring costs increase the growth rate.

But a lower monitoring cost also has a level effect by increasing the level of per capita GDP at the date of implementation of the policy. This follows by noting that a lower $\gamma$ reduces the minimum wealth that entrepreneurs need to enter the modern sector. ${ }^{23}$ Since per capita GDP is proportional to the fraction of entrepreneurs in the modern sector, relaxing the credit-constraint also raises the level of GDP.

Institutional reforms in a bank-based system, thus, encourage traditional sector entrepreneurs to participate in more gainful activities, thereby improving entrepreneurial income distribution. ${ }^{24}$ One healthy outcome is that it speeds up structural transformation the traditional sector declines in size and the modern sector expands.

A policy that lowers agency costs in a market-based system $(V)$, on the other hand, leads to faster growth but worsening wealth distribution. In particular, a lower agency cost results in a higher investment rate [by (4.6)], and faster growth for those entrepreneurs who have access to external finance. However, the minimum wealth required to qualify for external finance, $b_{L}^{*}$, is independent of $V$. So a lower $V$ has no impact on the size of the traditional sector. At the same time, by speeding up wealth accumulation among modern-sector entrepreneurs, it leads to rising entrepreneurial wealth inequality along the new balanced growth path.

Interestingly, lowering $\gamma$ or $v$ would raise GDP and improve the wealth distribution even in a market-based system. These cost parameters determine $b_{L}^{*}$ which is also the relevant cutoff wealth for entrepreneurs in a market-based system. Lower $\gamma$ or $v$ will allow some previously constrained entrepreneurs to get external finance: these entrepreneurs will rely at first on mixed finance, but gradually grow wealthy enough to qualify for only market finance.

These results indicate that developing countries may benefit more from bank-based sys-

\footnotetext{
${ }^{23}$ From equation (4.1) the minimum amount of initial funds required to qualify for entry into the modern sector is $b_{L}^{*}=\left[(1+\gamma)-\{\alpha A-v /(1-\pi)\} / R^{*}\right] q^{*}$. Clearly, $\partial b_{L}^{*} / \partial \gamma>0$ and $\partial b_{L}^{*} / \partial v>0$.

${ }^{24}$ Recall that along the balanced-growth path, incomes between modern-sector and traditional-sector entrepreneurs are diverging.
} 
tems. This is especially true in environments where setup costs are large relative to average wealth levels and when a more equitable income distribution is of paramount concern.

\section{Redistributive Policies}

Given that the traditional sector stagnates even as the modern-sector enjoys sustained income gains, a natural question to ask is whether policies could ameliorate this widening inequality. In a bank-based system, one possibility is to tax wealthier (unconstrained) entrepreneurs and use the proceeds to subsidize the banking sector. For instance, the subsidy may be provided every time a bank spends resources monitoring a borrowing firm. This is equivalent to a reduction in $\gamma$, the cost that is directly borne by banks. The outcome is a lower $b_{L}^{*}$ and a larger proportion of entrepreneurs in the modern-sector.

How long it takes for such a policy to pull out the entire traditional sector depends upon the initial size of this sector, and how high agency costs are. Moreover, subsidies to the banking sector will work well only if there are no agency problems within the banks, an assumption we have implicitly maintained in our analysis. If that were not the case, such subsidies could result in worse investment outcomes and efficiency loss.

A more desirable policy intervention may be to directly redistribute wealth from wealthier entrepreneurs to poorer ones. The effect on wealthier entrepreneurs would be similar to that under the previous policy, but providing additional wealth to credit-constrained entrepreneurs may enable all of them to eventually overcome $b_{L}^{*}$. Such a policy has the added benefit of working in a bank-based economy as well as a market-based one.

As in Banerjee and Newman (1993), neither type of policy intervention has to be permanent. Temporary subsidies enable constrained entrepreneurs to overcome $b_{L}^{*}$. A subsequent withdrawal of the subsidy does not push these entrepreneurial families back into the traditional sector as long as they have accumulated wealth beyond $b_{L}^{*}$ while the policy was in place.

On balance, therefore, we conclude that although there may not be distinct growth advantages to having a particular financial regime, bank-based systems have an edge along other dimensions. Intermediated finance confers certain benefits for economic development. Two different financial structures may lead to similar growth rates, but a bank-based system has a level effect on per capita income and leads to a faster structural transformation. Moreover, developing countries contemplating financial sector reforms to reduce agency problems in the loanable funds market will obtain higher economic payoffs under bank-based systems due to the structural transformation that results. Our analysis is, thus, complementary to 
some recent contributions, notably by Rajan and Zingales (1998b, 1999) and Tadesse (2001), which make a strong case for bank-based systems in developing countries.

\section{Conclusion}

The chief contribution of this paper has been to shed light on the ongoing debate about the relative merits of bank-based and market-based financial systems for growth and development. Many developing countries have been moving towards market-based systems in recent years without a clear consensus that such systems are necessarily better. Hence, it is important that growth theory addresses this debate to better inform policy-making.

From a growth perspective, we do not find that one type of system is invariably better than the other. Indeed, it is quite possible for two types of systems in two different countries to deliver similar growth rates of per capita GDP. Moreover, and consistent with recent crosscountry evidence, we argue that the quality of a country's financial and legal institutions are more important for its growth.

But bank-based systems have some advantages over those that are market-based. For one, levels of investment and per capita GDP are higher under a bank-based system. Bank monitoring resolves some of the agency problems and enable firms to borrow more. Armslength market finance plays no such role and results in a lower amount of external finance available to all firms.

Secondly, bank-based systems allow greater participation in manufacturing activities, by providing external finance to a larger number of entrepreneurs. The implication is that the traditional sector is smaller and wealth distribution better under such a system.

Policy reforms in a bank-based system raise the growth rate and reduce the size of the traditional sector; in a market-based system they improve growth but leave the traditional sector unaffected unless such policies also reduce the costs of intermediated finance. A temporary redistribution policy, under both financial regimes, has permanent effects on growth, distribution and relative size of the traditional sector. 


\section{Appendix}

\section{A.1. Positive Growth Rates}

In the intermediated finance regime the growth rate $g_{I}$ is defined by

$$
1+g_{I} \equiv(1-\beta)\left[\frac{[v /(1-\pi)] R^{*}}{v /(1-\pi)-\left[\alpha A-(1+\gamma) R^{*}\right]}\right]
$$

From Assumption 4 we have

$$
\begin{aligned}
& v /(1-\pi) \leq \frac{\alpha A-R^{*}(1+\gamma)}{1-(1-\beta) R^{*}} \\
& \Rightarrow 1-\frac{\alpha A-R^{*}(1+\gamma)}{v /(1-\pi)} \leq(1-\beta) R^{*} \\
& \Rightarrow(1-\beta)\left[\frac{[v /(1-\pi)] R^{*}}{v /(1-\pi)-\left[\alpha A-(1+\gamma) R^{*}\right]}\right] \geq 1 .
\end{aligned}
$$

It follows that $g_{I} \geq 0$.

Similarly, using Assumption 5, it can be shown that the growth rate under the unintermediated finance regime, $g_{U} \geq 0$.

\section{A.2. Investment Size in Bank-based and Market-based Systems}

Here we consider if two countries that share the same growth rate but under different financial systems also invest equal amounts.

Take two countries, 1 and 2 where 1 uses mixed finance, but 2 uses unintermediated finance. Suppose both have the same growth rate so that

$$
\frac{\alpha A-\left(1+\gamma_{1}\right) R^{*}}{v_{1} /(1-\pi)}=\frac{\alpha A-R^{*}}{V_{2} /(1-\pi)} .
$$

We shall compare the size of investment any particular entrepreneur with internal funds $b^{j}$ makes in each of these countries.

We have

$$
\begin{aligned}
q_{1}^{j} & \geq q_{2}^{j} \\
& \Leftrightarrow\left(1+\gamma_{1}\right)-\frac{1}{R^{*}}\left(\alpha A-\frac{v_{1}}{1-\pi}\right) \leq 1-\frac{1}{R^{*}}\left(\alpha A-\frac{V_{2}}{1-\pi}\right) \\
& \Leftrightarrow \frac{V_{2}-v_{1}}{1-\pi} \geq \gamma_{1} R^{*} .
\end{aligned}
$$


From (8.1),

$$
\begin{aligned}
\frac{v_{1}}{V_{2}} & =\frac{\alpha A-\left(1+\gamma_{1}\right) R^{*}}{\alpha A-R^{*}}=1-\frac{\gamma_{1} R^{*}}{\alpha A-R^{*}} \\
& \Rightarrow 1-\frac{v_{1}}{V_{2}}=\frac{\gamma_{1} R^{*}}{\alpha A-R^{*}} \\
& \Rightarrow \frac{V_{2}-v_{1}}{1-\pi}=\frac{V_{2}}{1-\pi} \frac{\gamma_{1} R^{*}}{\alpha A-R^{*}} .
\end{aligned}
$$

Substituting this into the LHS of (8.2),

$$
\begin{aligned}
\frac{V_{2}}{1-\pi} \frac{\gamma_{1} R^{*}}{\alpha A-R^{*}} & \geq \gamma_{1} R^{*} \\
& \Leftrightarrow \frac{V_{2}}{1-\pi} \geq \alpha A-R^{*} .
\end{aligned}
$$

Now from the participation constraint of the entrepreneur in country 2 ,

$$
z^{j}=\left(\alpha A-R^{*}\right) q_{2}^{j}+R^{*} b^{j}=\frac{V_{2}}{1-\pi} q_{2}^{j}
$$

we have,

$$
\frac{V_{2}}{1-\pi}>\alpha A-R^{*}
$$

as long as $b^{j}>0$. Hence, investment size in country 2 is smaller for every entrepreneur in the modern-sector, i.e., $q_{1}^{j}>q_{2}^{j}$. Consequently, per capita GDP in country 1 is larger, i.e., $Y_{1}>Y_{2}$.

\section{A.3. $b_{L}^{*}$ in Bank-based and Market-based Systems}

We show here that $b_{L}^{*}$ is lower for a bank-based economy than a market-based one, if both have the same growth rate. Once again consider country 1 with a bank-based system and country 2 with a market-based one and, $g_{1}=g_{2}$. We need to show that $b_{L, 1}^{*}<b_{L, 2}^{*}$.

From Proposition 3, we have

$$
\begin{gathered}
\frac{\alpha A-R^{*}\left(1+\gamma_{1}\right)}{v_{1} /(1-\pi)}>\frac{\alpha A-R^{*}}{V_{1} /(1-\pi)}, \text { and } \\
\frac{\alpha A-R^{*}\left(1+\gamma_{2}\right)}{v_{2} /(1-\pi)}<\frac{\alpha A-R^{*}}{V_{2} /(1-\pi)} .
\end{gathered}
$$

Also, $g_{1}=g_{2}$ implies that

$$
\frac{\alpha A-R^{*}\left(1+\gamma_{1}\right)}{v_{1} /(1-\pi)}=\frac{\alpha A-R^{*}}{V_{2} /(1-\pi)}
$$


Combining these three relations we have the following inequality:

$$
\begin{aligned}
\frac{\alpha A-R^{*}\left(1+\gamma_{1}\right)}{v_{1} /(1-\pi)} & >\frac{\alpha A-R^{*}\left(1+\gamma_{2}\right)}{v_{2} /(1-\pi)} \\
& \Rightarrow \frac{v_{2}-v_{1}}{1-\pi}>\frac{v_{1}}{1-\pi} \frac{R^{*}\left(\gamma_{1}-\gamma_{2}\right)}{\alpha A-R^{*}\left(1+\gamma_{1}\right)}
\end{aligned}
$$

Now, from entrepreneur- $j$ 's incentive constraint in country 1 , we have

$$
z_{1}^{j}=\left[\alpha A-\left(1+\gamma_{1}\right) R^{*}\right] q_{1}^{j}+R^{*} b^{j}=\frac{v_{1}}{1-\pi} q_{1}^{j},
$$

so that, for any $b^{j}>0$,

$$
\frac{v_{1}}{1-\pi}>\alpha A-\left(1+\gamma_{1}\right) R^{*}
$$

Combining this with (8.3) above, we get

$$
\frac{v_{2}-v_{1}}{1-\pi}>R^{*}\left(\gamma_{1}-\gamma_{2}\right)
$$

To have $b_{L, 1}^{*}<b_{L, 2}^{*}$, we need that

$$
\begin{aligned}
\frac{q^{*}}{R^{*}}\left[\frac{v_{1}}{1-\pi}-\left\{\alpha A-\left(1+\gamma_{1}\right) R^{*}\right\}\right] & <\frac{q^{*}}{R^{*}}\left[\frac{v_{2}}{1-\pi}-\left\{\alpha A-\left(1+\gamma_{2}\right) R^{*}\right\}\right] \\
& \Leftrightarrow \frac{v_{2}-v_{1}}{1-\pi}>R^{*}\left(\gamma_{1}-\gamma_{2}\right),
\end{aligned}
$$

which holds by (8.4). 


\section{References}

[1] Allen, Franklin and Douglas Gale (2000), Comparing Financial Systems, Cambridge, MA, MIT Press.

[2] Allen, Franklin and Douglas Gale (2001), "Comparative Financial Systems: A Survey", mimeo, New York University.

[3] Arrow, Kenneth J. (1962), "The Economic Implications of Learning by Doing," Review of Economic Studies, vol. 29, pp. 155-73.

[4] Banerjee, Abhijit and Andrew Newman (1993), "Occupational Choice and the Process of Development," Journal of Political Economy, vol. 101, pp. 274-98.

[5] Bernanke, Ben and Mark Gertler (1989), "Agency Costs, Net Worth and Business Fluctuations", American Economic Review, vol. 79, pp. 14-31.

[6] Bernanke, Ben, Gertler, Mark and Simon Gilchrist (2000), "The Financial Accelerator in a Quantitative Business Cycle Framework", in The Handbook of Macroeconomics, North-Holland.

[7] Bencivenga, Valerie and Bruce Smith (1991), "Financial Intermediation and Endogenous Growth", Review of Economic Studies, vol. 58, pp. 195-209.

[8] Boot, Arnoud W. A. and Anjan V. Thakor (1997), "Financial System Architecture," Review of Financial Studies, vol. 10, pp. 693-733.

[9] Boyd, John H. and Edward Prescott (1986), "Financial Intermediary-Coalitions," Journal of Economic Theory, vol. 38, pp. 211-32.

[10] Boyd, John H. and Bruce D. Smith (1998), "The Evolution of Debt and Equity Markets in Economic Development," Economic Theory, vol. 12, pp. 519-60.

[11] de la Fuente, Angel and Jose Maria Marin (1996), "Innovation, Bank Monitoring, and Endogenous Financial Development", Journal of Monetary Economics, vol. 38, no. 2, pp. 269-301.

[12] Diamond, Douglas (1984), "Financial Intermediation and Delegated Monitoring," Review of Economic Studies, vol. 51, pp. 393-414. 
[13] Diamond, Douglas (1991), "Monitoring and Reputation: The Choice between Bank Loans and Directly Placed Debt", Journal of Political Economy, vol. 99, pp. 689-721.

[14] Galor, Oded and Joseph Zeira (1993), "Income Distribution and Macroeconomics," Review of Economic Studies, vol. 60, pp. 35-52.

[15] Gerschenkron, Alexander (1962), Economic Backwardness in Historical Perspective, Cambridge, MA: Harvard University Press.

[16] Goldsmith, Raymond (1969), Financial Structure and Development, Yale University Press, New Haven, CT.

[17] Greenwood, Jeremy and Boyan Jovanovic (1990), "Financial Development, Growth and the Distribution of Income", Journal of Political Economy, vol. 98, no. 5, pp. 1076-107.

[18] Greenwood, Jeremy and Bruce Smith (1997), "Financial Markets in Development, and the Development of Financial Markets," Journal of Economic Dynamics and Control, vol. 21, pp. 145-81.

[19] Gurley, John and E. Shaw (1955), "Financial Aspects of Economic Development," American Economic Review, vol. 45, pp. 515-38.

[20] Hellwig, Martin (1991), "Banking, Financial Intermediation and Corporate Finance", in European Financial Integration, (eds.) Alberto Giovannini and Colin Mayer, Cambridge University Press, U.K.

[21] Hicks, John (1969), A Theory of Economic History, Oxford, UK, Clarendon Press.

[22] Holmstrom, Bengt (1996), "Financing of Investment in Eastern Europe," Industrial and Corporate Change, vol. 5, pp. 205-37.

[23] Holmstrom, Bengt and Jean Tirole (1997), "Financial Intermediation, Loanable Funds, and the Real Sector," Quarterly Journal of Economics, vol. 112, pp. 663-91.

[24] La Porta, Rafael, Florencio Lopez-de-Silanes, Andrei Shleifer and Robert Vishny (1997), "Legal Determinants of External Finance," Journal of Finance, vol. 52, pp. 1131-50.

[25] La Porta, Rafael, Florencio Lopez-de-Silanes, Andrei Shleifer and Robert Vishny (1998), "Law and Finance," Journal of Political Economy, vol. 106, pp. 1113-55. 
[26] Levine, Ross (1997), "Financial Development and Economic Growth: Views and Agenda", Journal of Economic Literature, vol. 35, pp. 688-726.

[27] Levine, Ross (2000), "Bank-based or Market-Based Financial Systems: Which is Better?", mimeo, University of Minnesota.

[28] Mayer, Colin (1988), "New Issues in Corporate Finance", European Economic Review, vol. 32 , pp. 1167-89.

[29] North, Douglass C. (1981), Structure and Change in Economic History, New York, W. W. Norton.

[30] Rajan, Raghuram and Luigi Zingales (1998a), "Financial Dependence and Growth", American Economic Review, vol. 88, pp. 559-86.

[31] Rajan, Raghuram and Luigi Zingales (1998b), "Which Capitalism? Lessons from the East Asian Crisis," Journal of Applied Corporate Finance, vol. 11, no. 3, pp. 40 - 48.

[32] Rajan, Raghuram and Luigi Zingales (1999), "Financial Systems, Industrial Structure and Growth", mimeo, University of Chicago.

[33] Romer, Paul (1986), "Increasing Returns and Long-Run Growth," Journal of Political Economy, vol. 92, pp. 1002-37.

[34] Scharfstein, David (1988), "The Disciplinary Role of Takeovers", Review of Economic Studies, vol. 55, pp. 185-99.

[35] Tadesse, Solomon (2001), "Financial Architecture and Economic Performance: International Evidence", mimeo, University of South Carolina.

[36] Williamson, Stephen (1986), "Costly Monitoring, Financial Intermediation and Equilibrium Credit Rationing", Journal of Monetary Economics, vol. 18, pp. 159-179.

[37] Williamson, Stephen (1987), "Financial Intermediation, Business Failures, and Real Business Cycles," Journal of Political Economy, vol. 95, no. 6, pp. 1196-1216. 


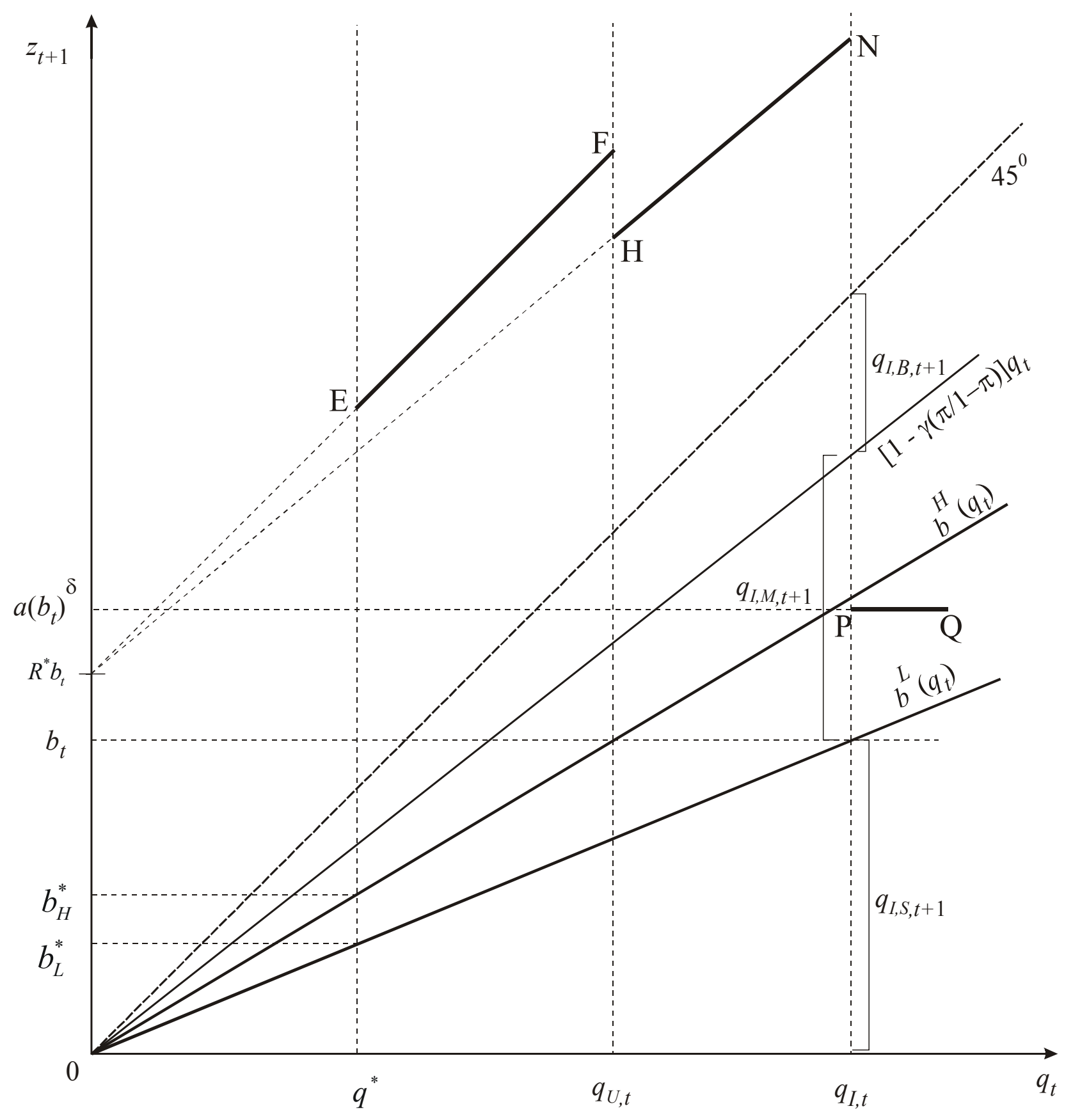

Figure 1(a): Investment Choice in a Bank-based System 


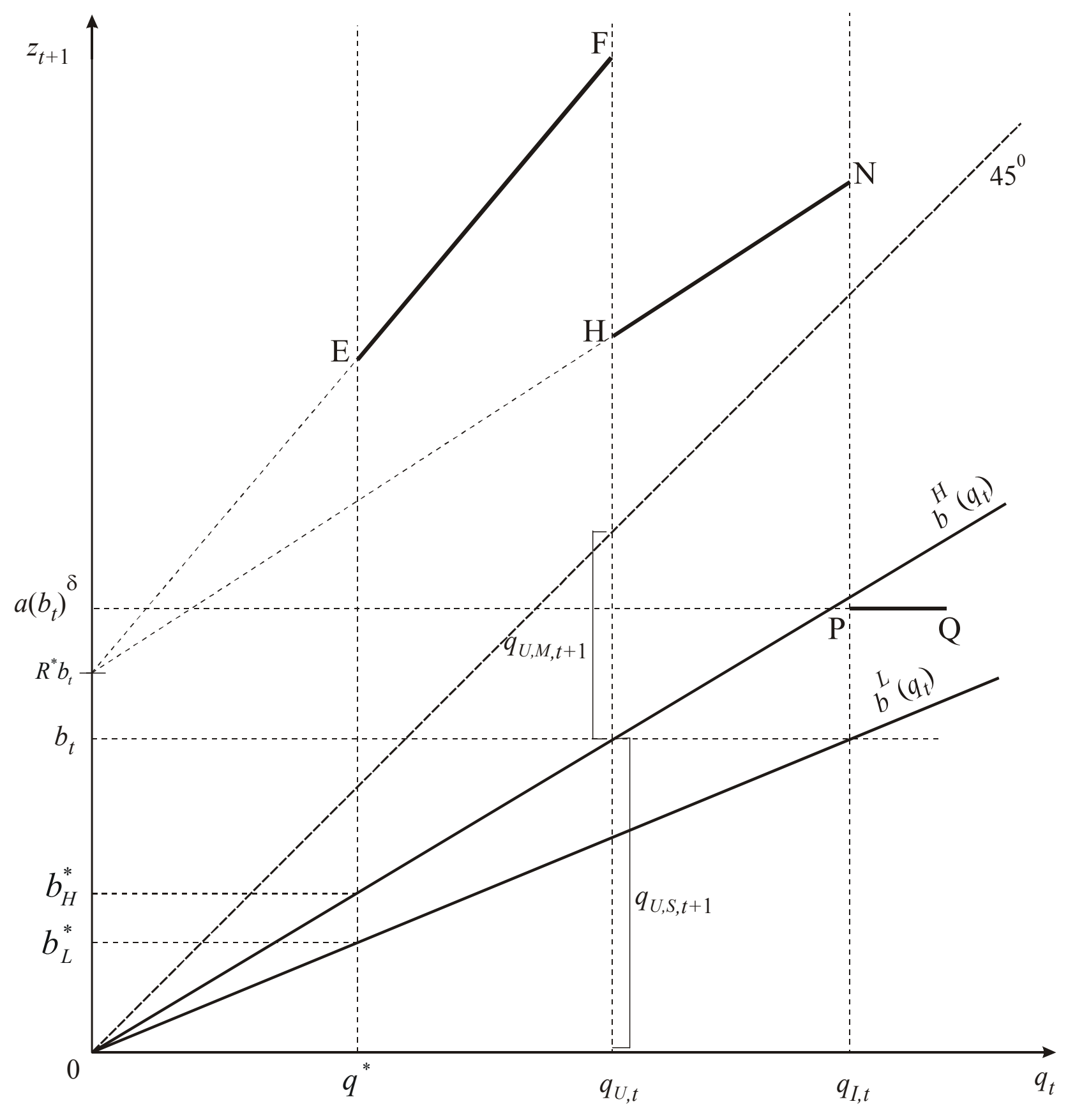

Figure 1(b): Investment Choice in a Market-based System 